\title{
INDONESIAN INTERFERENCE TOWARD ENGLISH USED ON OUTDOOR ADVERTISEMENT BOARDS AND BANNER IN SUKOHARJO, CENTRAL JAVA
}

\author{
Giyatmi Giyatmi, Purwani Indri Astuti, Ratih Wijayava, Sihindun Arumi \\ University of Veteran Bangun Nusantara Sukoharjo \\ giyatmi85jimmy@gmail.com, indripuspo@gmail.com, ratihwijayava@gmail.com, arumisihindun@yahoo.com
}

\begin{abstract}
Interference is a common phenomenon in second language learning. However, the researchers are interested in analysing interference from another point of view. This research aims at finding the types of Indonesian interference toward English found in outdoor advertisement boards and banners in Sukoharjo, Central Java. The researchers use some theories dealing with interference such as the definition of interference and type of interference. This research belongs to a descriptive qualitative research. Data of this research are English words, phrases, and sentences consisting of Indonesian interference toward English used in outdoor advertisement boards and banner. The data are taken from outdoor advertisement boards and banners in Sukoharjo, Central Java. The technique of data collection used is observation then followed by writing technique. English words, phrases, and sentences with no interference are reduced. Then the data found are encoded with No data/Data/Kinds of Interference. The researchers use theory triangulation during this research. The researchers found 74 data of Indonesian interference toward English in outdoor advertisement boards and banners in Sukoharjo, Central Java. After analysing the data, the researchers found that there are 6 types of Indonesian interference toward English; (1) syntactic interference in the formation of phrase and sentence (2) Lexical interference in the case of borrowing words adapted into Indonesian spelling (3) Phonological interference in vowel sounds, consonant sounds, and semivowel sounds (4) Morphological interference in the process of affixation (5) Graphic interference in the spelling principle (6) Translation interference which happens because of direct translation.
\end{abstract}

Keywords: advertisement, language interference, kinds of interferences

\section{INTRODUCTION}

Interference known as language transfer is a common phenomenon in multilingual society. It is a phenomenon in which the language users applying their first language knowledge to a second language they are studying. Language interference mostly happens in language learning where two or three languages often intersect each other. Meanwhile, Dulay (1982) says that interference is the automatic transfer because of the language learners' habit to their first language.

Apart from the interference, which is so common in second language learning, there is an interesting phenomenon in Indonesia. Indonesian interference toward English can be found in the use of English in the advertisement such as on banner. English is a foreign language in Indonesia but due to its prestige reason, some of the advertisements use English. The low knowledge of English often results in the interference. 
The following are examples of interesting banners found near one of the private universities in Solo, Central Java, Indonesia.
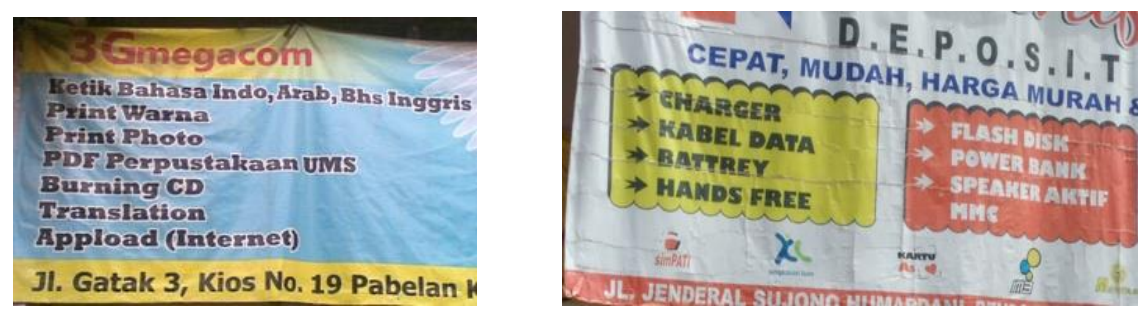

Banner with Indonesian Interference toward English

The first example is a computer rental banner offering some services such as printing, PDF converting, CD burning, translation, and upload (internet). There is Indonesian interference toward English found in the banner, i.e. the use of the word Appload instead of Upload. It is one of Indonesian interference found in the banner. The second example is a banner of a cellular counter, which sells some items dealing with mobile phone accessories such as power bank, MMC, active speaker. The interference happens because the banner uses the word speaker *aktif instead of active speaker. There are still many banners and boards with Indonesian interference toward English found.

The use of*appload instead of upload is due to the phonological interference. Upload $/ \Lambda$ pləod/, the letter $U$ is pronounced as $[\Lambda]$, which is similar to the vowel sound [a] in Indonesian; so that, to make the word easily pronounced the use of appload is preferred in the banner. Meanwhile, the use of speaker aktif is due to the syntactical and lexical interference of Indonesian toward English. The correct order should be active speaker instead of speaker aktif. Active Speaker is a noun phrase with the speaker as the headword and active as the modifier. In English, the modifier should be in front of the headword. However, the headword of Indonesian phrase, in this case, appears after what is headword in English so it is written speaker aktif. The Indonesian language borrows the word active from English. The borrowing word (active) then adjusted with Indonesian spelling so it becomes aktif. The interference happens due to letter $\mathrm{C}$ in English spelling is usually written into letter $\mathrm{K}$ in Indonesian spelling system.

The writers are interested to analyse the phenomena of Indonesian interference toward English found in advertisement banners and board around Sukoharjo, Central Java. The writers focused the study on kind of Indonesian. This study aims at finding kinds of interference found in advertisement banner and board.

\section{MATERIALS AND METHODS}

\subsection{LITERATURE REVIEW}

\subsubsection{LANGUAGE INTERFERENCE}

It is necessary to remember about language contact when discussing about interfeerence. Thomason in (Sarfaz et.al, 2016: 684) defines that language contact is the use of more than one language in the same place and at the same time in which the speakers of the two languages interact and influence each other. Language contact leads to bilingualism, a situation in which speakers use more than one language. A community exposed with more than one language has a big chance of experiencing interference because of the language contact. The speakers of an L2 will always be influenced by their L1 in some ways when they use the L2. It sometimes disturbs the process of L2 learning. 
Language interference is mostly triggered by bilingualism (Anca Sirbu, 2015; 376). The use of many languages in a bilingual community gives a big opportunity for interference. Weinreich in Dulay defines interference as those instances of deviation from the norms of either language which occur in the speech of bilinguals as a result of their familiarity with more than one language, i.e. as a result of language contact (1982;99). In a bilingualism community, mother tongue or native language or parent language play significant roles in language interference. Mother tongue interference refers to the influence of the native language of the learner on his/her acquisition of the target language (Rana Abid Thyab,2016;1).

Dulay defines interference as the automatic transfer, due to habit, of the surface structure of the first language onto the surface of the target language (1982). In addition, Ali and Elham (2015; 2112), mention that the first language (L1) has an effect on the second language (L2) acquisition and L1 (first language) interferes with the acquisition of L2 (second language). Furthermore, James in (Gvarishvili, 2015: 1566) states that while learning the new language, adult learners are also applying some rules from their first language onto the target language, this phenomenon is known as learning transfer.

Dweik and Othman (2017: 66) mention that interference can cause deviation in the target language as the result of the transfer from (L1) to (L2). The learners' transfer of L1's rules into the L2's rules neglects that there could be a difference of rules between those two languages so it can cause some deviation or errors. Nunan in Sabbah $(2015 ; 270)$ states that when the rules of L1 and L2 are not the same, errors can take place as a result of interference between the two languages. It is clear that interference is a kind of language deviation in the case of applying language norms or rules as the results of familiarity with that of another language which often happens in a community with more than one languages exposure.

L1 interference is also known as linguistic interference, transfer or cross-linguistic influence. Odlin in (Erarslan and Hol, 2014; 5) states that transfer is the influence resulting from similarities and differences between the target language and any other language that has been previously (and perhaps imperfectly) acquired. Brown (in Dweik and Othman, 2017:66) adds transfer as the influence which occurs between the native language (L1) and the second language (L2) because of the similarities and differences between them. Transfer or language transfer is a very common phenomenon in the process of second language learning.

Transfer can be classified into the positive transfer and negative transfer (Sabbah, 2015:271). The positive transfer occurs when the rules of the first language have a positive influence in learning the second language. It happens since there are a lot of similarities between the first and second language. Meanwhile, the negative language transfer takes place when the rules of the first language inhibit the process of second language learning. It can happen due to the dramatic difference between the first and the second language. Interference is sometimes called negative language transfer because it uses the rules of native language to the target language that results in language mistakes.

Furthermore, Lekova $(2010 ; 321)$ mentions that there are two kinds of language interference; inter-language and intra-language which are closely related to the sources of errors in the process of interference. Sabbah $(2015 ; 270)$ mentions that there are two sources contributed to the leaner's native language or his/her target language namely inter-lingual errors and intra-lingual errors. Corder in Sabbah $(2015 ; 270)$ adds that inter-lingual errors take place when the learners' first language habits (pattern, systems or rule) interfere or prevent him/her from acquiring the pattern and rules of the second language. Briefly, in inter-language interference, mistakes appear because of the negative transfer of habits from the native language. 
Intra-language interference happens when the learners' mistakes are under the influence of the language knowledge and established habits that they have already acquired in the second language they are learning now. These errors including generalization, substitution, and other process are caused by some process that learners recourse to when learning the second language. (Sabbah, 2015; 271)

\subsubsection{TYPES OF LANGUAGE INTERFERENCE}

Interference can happen at different linguistic levels. Anca Sirbu (2015; 376) defines interference as the transfer of elements of one language that can take place in terms of lexis, grammar, phonology or orthography alteration. Suleymanov (2016; 2039) divides the interferences into the following classes such as lexical, syntactic and grammatical interference. Havlaskova in (Dweik and Othman, 2017; 1) describes that interference as a phenomenon that may occur at the level of a word, a phrase, an idiom, a metaphor or a term a whole syntactic structure when translators transfer some source texts into target text influenced by the aspect of the source language. Odlin (in Suhono, 2018; 478) classifies the language transfer into four types that may occur at phonological interference, morphological interference, syntactical interference, and lexical interference. Abdul Chaer and Leoni Agustina (2010; 123) mentions that there are three kinds of linguistic interference, namely phonological interference, morphological interference, and syntactic interference.

Lexical interference is at the level of words. Suhono $(2018 ; 478)$ mentions that lexical interference occurs when there is a transfer of morpheme or word of the first language into second language use. In the level of lexis, linguistic interference can be seen in the case of borrowing words from one language. Lexical interference influences the development of vocabulary such as borrowing word. Besides, it includes the word transformation as to sound more natural in the other language. The transformation can cause some changes in spelling. Incorrect or inappropriate direct translation of a concept can cause lexical interference (Suleymanov, 2016: 2039).

In the level of phonology, linguistic interference deals with intonation, pitch, accent and speech sound of the first or native language that influence the second language. In terms of pronunciation language interference and its extent are defined by a number of factors, including the similarity of the phonetic system of the language in contact (Snesareva, 2016; 214). Phonological interference occurs when the speaker identifies the sound of the first language system used in the target language, after that the speakers pronounce again and regulates the pronunciation using the law of the source language phoneme (Suhono, 2018; 478). Phonological interference happens when the pronunciation of the first language influences that of the second language. For example, Javanese people like to add nasal sound [n,m] so certain words such as mBali, mBandung, nDepok. Most of the Indonesian learners who learn English will pronounce time [taim] with no aspirated instead of time [thaim] with aspirated.

In the grammar level, linguistic interference may come when the speakers apply their L1's grammar rules on the L2's grammar rules. Interference in the grammar is also called by syntactical interference. Bennui $(2008 ; 78)$ mentions that the L1 syntactic interference deals with the errors found in grammar level. Jianhua in (Suhono, 2018; 478) states that syntactical transfer involves the transference of syntactical structures, such as article (a, an, and the), word order, relative clauses (that, which, who, whom, etc), negation and so on. Syntactic interference happens when the language learners use their first language syntactic knowledge on their second language learning. Indonesian has no auxiliary to be such as am, is, are, was, were, and been. The absence of auxiliary to be in the Indonesian language will influence Indonesian learners 
when they make an English nominal sentence. Most of them will write she a teacher* instead of she is a teacher. Morphological interference can be seen in the word formation using affixes that belong to the first language. Reduplication in Indonesia can be done by reduplicating the base such as rumah-rumah, jalan-jalan. So some English learner will say *walking-walking (jalanjalan) instead of walking around (jalan-jalan).

As quoted from http://www.geocities.ws/dyakov_andriy/Dissertation/chapter_1.html, there is another type of interference named graphic interference. Graphic interference influences the writing system and the spelling principle of the national orthography. Graphic interferences consist of graphitization (creation of a writing system), elaboration of spelling rules, graphic influence upon a language etc. Orthography reform is a kind of graphical interference too. Sinha $(2009 ; 121)$ mentions that alphabetical shapes and structures of the first language would create interference in the second language.

\subsection{MeThODOLOGY}

This research belongs to a descriptive qualitative research. This research tries to describe the phenomenon of Indonesian interference toward English found in outdoor advertisement boards and banners found in Sukoharjo, Central Java. The data of the research are the English words, phrases, and sentences found in outdoor advertisement boards and banner containing interference. The techniques of collecting data used in the research are observation followed by a writing technique. The observation is done in several areas such as Solo Baru, Kartasura and Sukoharjo Kota, Central Java. Data analysis consists of data reduction, data display, and data verification. The data with no interference are omitted directly. Then data found are encoded in the following way No Data/Data/Kind of Interference. Data is displayed by using narration and table. The last step of data analysis is data verification which is done based on the results of the discussion on the kind of Indonesian interference toward English found in outdoor advertisement boards and banners found in Sukoharjo, Central Java. The researchers use theory triangulation during this research.

\section{RESULTS AND DISCUSSION}

Having reduced the data, the researchers found 72 data. After analyzing them, the researcher found that there are six types of interference such as phonological interference (24), morphological interference (5), syntactical interference (8), graphical interference (18), lexical interference (12), and translation interference (5).

\subsection{PHONOLOGICAL INTERFERENCE}

Phonological interference happens when the Indonesian pronunciation system is affected the way of pronouncing the English words found in the data. Phonological interferences happen when the English words are pronounced in Indonesian pronunciation system. It is to make the words are easily pronounced. There are 24 data dealing with phonological interference. In this research, the researchers found phonological interference occurring in vowel sounds, consonant sounds, and semivowel sounds.

\subsubsection{VOWEL, SEMI VOWEL, AND DIPHTHONG SOUND}

The examples of phonological interference in vowel sounds are in data 07/appload/PI,

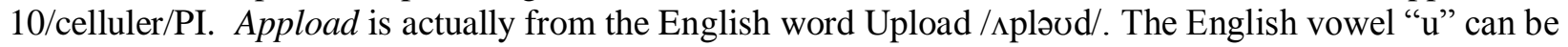
pronounced in many ways, one of them is $/ \Lambda /$, an open-mid back unrounded vowel which is similar to the sound [a] in Indonesian. So to make it easily pronounced the word is written into Appload. The banner maker has recognized the situation in which most of the readers are probably going to read the word Upload into / upləovd/. To anticipate the pronunciation of /u/, close back rounded vowel, on the data, the banner maker chooses to write Appload instead of Upload. The similar case is in the word drum band which is written into *dram band. 
Celluler is from the word Cellular/scljolæ/. The English vowel "a" can be pronounced in many ways, one of them is / æ /, the near-open front unrounded vowel in English which is similar to the sound [e] in Indonesian. It can be found in the data such as transformed, character, families, chapter, aboriginal, hadn't, and fact. All the bold vowels in the data should be pronounced as sound / æ/, however, they are modified into sound /a/. There is a big chance for the English learners in Indonesia to pronounce it that way in which they will pronounce words as what is written not what is pronounced. To anticipate it, the banner maker writes celluler instead of cellular. Another example is English diphthong [ou] pronounced as [ou] so that is it written into laundry in Indonesian. The semivowel sound interference can be found in 31/hendicamp/PI. The semivowel sound in this datum is [y]. Hendicamp should be written handy cam /handikæm/. The sound [y] is pronounced as [i] in Indonesian.

\subsubsection{CONSONANT SOUND}

The examples of phonological interference in consonant sound can be seen in 15/cloting/PI, 29/carger/PI, 59/sift/PI. Cloting is from the English word clothing //kləoðıy/. In English pronunciation, the letter th in this example is pronounced [ð], voiced dental fricative sound, which is similar to [t], voiced interdental stop sound in Indonesian. Consonant cluster /ck/ is pronounced into [k], voiceless velar plosive, and written using letter $\mathrm{k}$ in Indonesian. So the forms of chikend, stiker, and loket are preferred to chicken, sticker, and locket.

Carger should be written into charger /t $\int \mathrm{a}(\mathrm{r}) \mathrm{d}$ )/. In English pronunciation, the letter ch in the example is pronounced as [t $\mathrm{f}]$, voiceless post-alveolar affricate sound, voiceless palatal affricate sound, which is similar to [c], voiceless palatal affricate sound, in Indonesian. *Sift should be written into shift $/ \int \mathrm{Ift} /$. The letter sh in the example is pronounced [S], voiceless post-alveolar fricative, which is similar to [s], voiceless alveolar fricative sound in Indonesian. The simplification of /th/ into /t/, /ch/ into /c/, /sh/ into /s/ is due to easy and simple pronunciation and writing for Indonesian people.

\subsection{MORPHOLOGICAL INTERFERENCE}

There are 5 data of morphological interference occurred in the form of affixation. The writers found two forms of morphological interference, namely the omission of affix and the addition of an affix.

\subsubsection{AFFIX OMISSION}

The omission of affix $-\mathrm{s}$ in the noun as a plural marker such as in 21/contact person/MI and 125 selected item/MI. The words person and item in the example should be written in the plural forms because those refer to plural nouns. However, there is no affix-s in the nouns attached. It is due to the absence of to pluralize noun in the Indonesian language.

Another example is the omission of affix $-\mathrm{s}$ in the verb as a Simple Present Tense marker such as in 54/proudly present/MI. The verb Present should be written Presents because the tense used is Present Tense with the third person singular subject. However, it is written with no suffix $-\mathrm{s}$ in the data. It happens due to the absence of tense in the Indonesian language.

\subsubsection{AFFIX ADDITION}

The other process of morphological interference found in this research is the addition of an affix. The interference happens because of the use of Indonesian affix meN- to the English verb such as 12/Nge-root/MI and 47/nge-hang/MI.

\subsection{SYNTACTICAL INTERFERENCE}

There are 8 data dealing with syntactical interference. Interference happens in the phrase and sentence formation. There are four data dealing with phrase formation and four data on sentence formation. 


\subsubsection{PHRASE FORMATION}

In the phrase formation, the interference happens in the case of word order especially in the formation of the noun phrase and verb phrase. The example of interference in the noun phrase can be found in data 69/speaker active/SI. The construction of the phrase on the data uses Indonesian construction of phrase in which a modifier comes after the headword. On the other hand, English construction of phrase is modifier then headword, so it should be Active Speaker. Meanwhile, interferences in verb phrase are in data 19/support by/SI and 64/design by/SI. Those phrases should be Supported by and Designed by. Those phrases are in passive form so they should use past participle (V3) by adding the suffix -ed after the verb. Due to the lack of grammatical knowledge, the creator of the banner did not add suffix-ed after the verb. Let alone, there is no changing of verb form in Indonesian.

\subsubsection{SENTENCE FORMATION}

The first example is 40/Lets join with us/SI. Lets comes from Let us which is shortened and separated by (') so it becomes Let's. The same datum applies an unnecessary preposition with after the verb so that there is interference. The right form of the sentence should be Let's join us. The same datum can be found in 41/Join with Geography Education.

\subsection{GRAPHIC INTERFERENCE}

Graphic interference occurs when it deals with the spelling principle. There are 18 data dealing with graphic interference. The interference happens in three different ways. First is letter omission. It means there are some letters omitted from the correct English words. The second is letter addition to the English words and the last one is the spelling changing.

\subsubsection{LETTER OMISSION}

Vowel letter omission occurs when there is an omission of single vowel letter such as perfume becomes parfum. Double vowel letter omission occurs in the word shoting (from shooting) and salon (from saloon). Meanwhile, consonant letter omission occurs when there is omission one consonant letter such as in comunity (community), expres (express), tubles (tubeless) and colection (collection). The omission of vowel and consonant letters is to simplify the form; in addition, this omission has no effect on the pronunciation.

\subsubsection{LETTER ADDITION}

Letter addition occurs when there are the vowel or consonant letters added to words. The writers only found 3 data dealing with letter addition. The data includes in letter addition, for examples are 35/repaire/GI, 49/merek/GI, and 23/chickend/GI. Repaire and Merek apply vowel letter addition. Repaire is from Repair + e. There is the unknown reason behind this addition. Meanwhile Merek is derived from Merk that is inserted with a vowel -e-. This insertion is to make the word pronounced easily. The consonant letter addition can be found in the word Chickend. Chickend is from the word chicken $+\mathrm{d}$.

\subsubsection{SPELLING CHANGING}

The last graphic interference deals with the spelling changing. It happens when Indonesian spelling interferes English spelling. The spelling changing has something to do with the pronunciation of certain words. The writers found 2 data dealing with the spelling changing such as;

Foto copy should be written in photocopy. The spelling changing happens in the changing of the consonant cluster /ph/ into /f/. In English, consonant cluster /ph/ is pronounced into [f]. This pronunciation is similar to that of consonant $/ \mathrm{f} /$ in the Indonesian language. In addition, Indonesian does not have consonant cluster /ph/, so it is written into /f/ instead of $/ \mathrm{ph} / \mathrm{just}$ like in the word foto copy. Meanwhile, laundrie should be written in laundry. English semivowel /y/ is pronounced similar to Indonesian vowel /i/. It influences the use of laundrie instead of laundry. 


\subsection{LEXICAL INTERFERENCE}

The writers found 12 data with lexical interference. There are several examples of data dealing with lexical interference; Lexical interference happens in the case of borrowing English words that are adapted into Indonesian spelling. It gives a significant influence on the interference of Indonesian into English. The words on table 10 are from English and borrowed in Indonesian by adapting them into the Indonesian words, for instance, are the word active becomes aktif in Indonesian and locket is adapted into loket in Indonesia.

\subsection{TRANSLATION INTERFERENCE}

Interference occurs in the translation level. Most of the Indonesian learning English will translate the Indonesian sentences into English sentences directly without paying attention to English grammar which is so different from that of Indonesian. They tend to translate Indonesian sentences into English words by words. The researchers found 5 data dealing with direct translation interference such as $01 / 4$ days again/TI, 40/Lets join with us/TI, 53/pre merried education/TI. The sentence 4 days again is probably from the Indonesian sentence 4 hari lagi. The ads are found in front of the cafe shop that will open for the first time within 4 days. The form should be 4 more days. *Lets join with us means Bergabunglah dengan kami in Indonesian language. The right form should be Lets join us. Pre merried education means Pendidikan pranikah. It should be Pre marriage education.

\section{CONCLUSION}

Interference is a common phenomenon in a bilingual society where two languages or more influence each other. Language interference is usually in second language learning. However, it can also occur in other areas such as advertisement like the phenomenon found in Sukoharjo, Central Java, Indonesia. There are some advertisement boards and banners using English but the English used is still influenced by Indonesian as the first language (L1).

The writers 5 types of interference in advertisement boards and banners in Sukoharjo, Central Java, Indonesia, namely phonological interference, morphological interference, syntactical interference, graphical interference, lexical interference, and translation interference. Translation interference is an additional finding in this research.

Phonological interferences happen when the English words are pronounced in Indonesian pronunciation system. Those can be classified based on the sounds undergoing interference such as; vowel sounds, consonant sounds, and semivowel sounds. Morphological interference found in the form of affixation. There are two processes of morphological interference found in this research, the omission of the affix and the addition of an affix. Syntactic interference happens in the phrase and sentence formation. Graphic interference occurs when it deals with the spelling principle. Lexical interference happens in the case of borrowing words adapted into Indonesia spelling. Interference also found at the translation level. This kind of interference happens because of direct translation.

\section{REFERENCES}

Bennui,P., (2008), A Study of L1 Interference in the Writing of Thai EFL Students, Malaysian Journal of ELT Research, Vol.4, pp. 72-102

Chaer, A \& Leoni, A. (2010) Sosiolinguistik: Perkenalan Awal. Jakarta: PT Rineka Cipta

Dulay, H, Burt, M \&Krashen, S. (1982). Language Two. Oxford: Oxford University Press

Dweik, B.S., \& Othman, Z.A., Lexical and Grammatical Interference in the Translation of Written Texts from Arabic into English. Academic Research International Vol. 8(3). Pp 65-70

Erarslan, A. \&Hol, D., (2014), Language Interference on English: Transfer on the Vocabulary, tense and Preposition Use of Freshmen Turkish EFL Learners, ELTA Journal, Vol.2 No.2, pp. 4-22 
Gvarishvili,Z. (2013). Interference of L1 Preposition Knowledge in Acquiring Prepositional Usage in English, Procedia-Social and Behavioral Science 70, pp. 1565-1573 (Available online at www.sciencedirect.com)

Lekova.B. (2009). Language Interference and Methods of Its Overcoming in Foreign Language Teaching, Traika Journal of Science, Vol. 8, Suppl. 3, pp 320-324, ISSN 1313-7069 (print), ISSN 13133551 (online)

Sabbah, S.S (2015). Negative Transfer: Arabic Language Interference to Learning English, Arab World English Journal, No.4 May 2015, pp 269-288, ISSN: 2229-9327

Sarfraz, S., Manzoor,Z., \&Tariq,R., (2016). An Analysis of Grammatical Interference and Its Social Acceptability in Pakistani Context. Procedia-Social and Behavioral Science 232, pp. 684-688 (Available online at www.sciencedirect.com)

Sinha,A. , Banerjee,N., Sinha, A \&Shastri, R.K., (2009). Interference of First Language in the Acquisition of Second Langauge, Journal of Psychology and Counceling, Vol. 1(7), pp 117-122

Sirbu, A. (2015). Language Interference Triggered by Bilingualism, Naval Academy Scientific Bulletin, Volume XVIII Issue 1. Constanta:Naval Academy Press.

Suhono,S., Umar Al Faruq, Hasyim. (2018), Language Interference in EFL Students' Composition of IAIM NU Metro Lampung (available online at www.researchgate.net/publication/322220467)

Suleymanov, A.Y (2016). The Interference of the Language and the Teaching Method of the Foreign Language on the Basis of Native Language, International Journal of Information Research and Review, Vol.03, Issue, 03,pp.2037-2044

Thyab, R A (2016). Mother-Tongue Interference in the Acquisition of English Articles by L1 Arabic Students, Journal of Education and Practice, www.iiste.org, Vol.7, N0.3, ISSN 2222-1735 (paper) ISSN 2222-288X

(Online) www.geocities.ws/dyakov_andriy/Dissertation/chapter_1.html 